\section{To: (Receiving Organization) \\ Distribution}

5. Proj./Prog./Dept./Div.:

RPP Corrosion Probe

\section{Originator Remarks:}

This ATP will document the satisfactory operation of the corrosion monitoring cabinet destined for operation on tank 241-AN-104

11. Receiver Remarks:

11A. Design Baseline Document? $\square$ Yes $\square$ No

$\begin{aligned} & \text { 3. From: (Originating Organization) } \\ & \text { DST Maintenance \& Reliability Eng }\end{aligned}$
$\begin{aligned} & \text { 6. Design Authority/Design Agent/ceg. Engr.: } \\ & \text { EC Norman }\end{aligned}$
Resp.
peration on tank 241-AN-104
4. Related EDT No.:
$\mathrm{N} / \mathrm{A}$
7. Purchase Order No.:
$\mathrm{N} / \mathrm{A}$
9. Equip./Component No.:
$\mathrm{N} / \mathrm{A}$
10. System/Bldg./Facility:
$\mathrm{N} / \mathrm{A}$
12. Major Assm. Dwg. No.:
$\mathrm{N} / \mathrm{A}$

13. Permit/Permit Application No.:

N/A

14. Required Response Date:

$\mathrm{N} / \mathrm{A}$

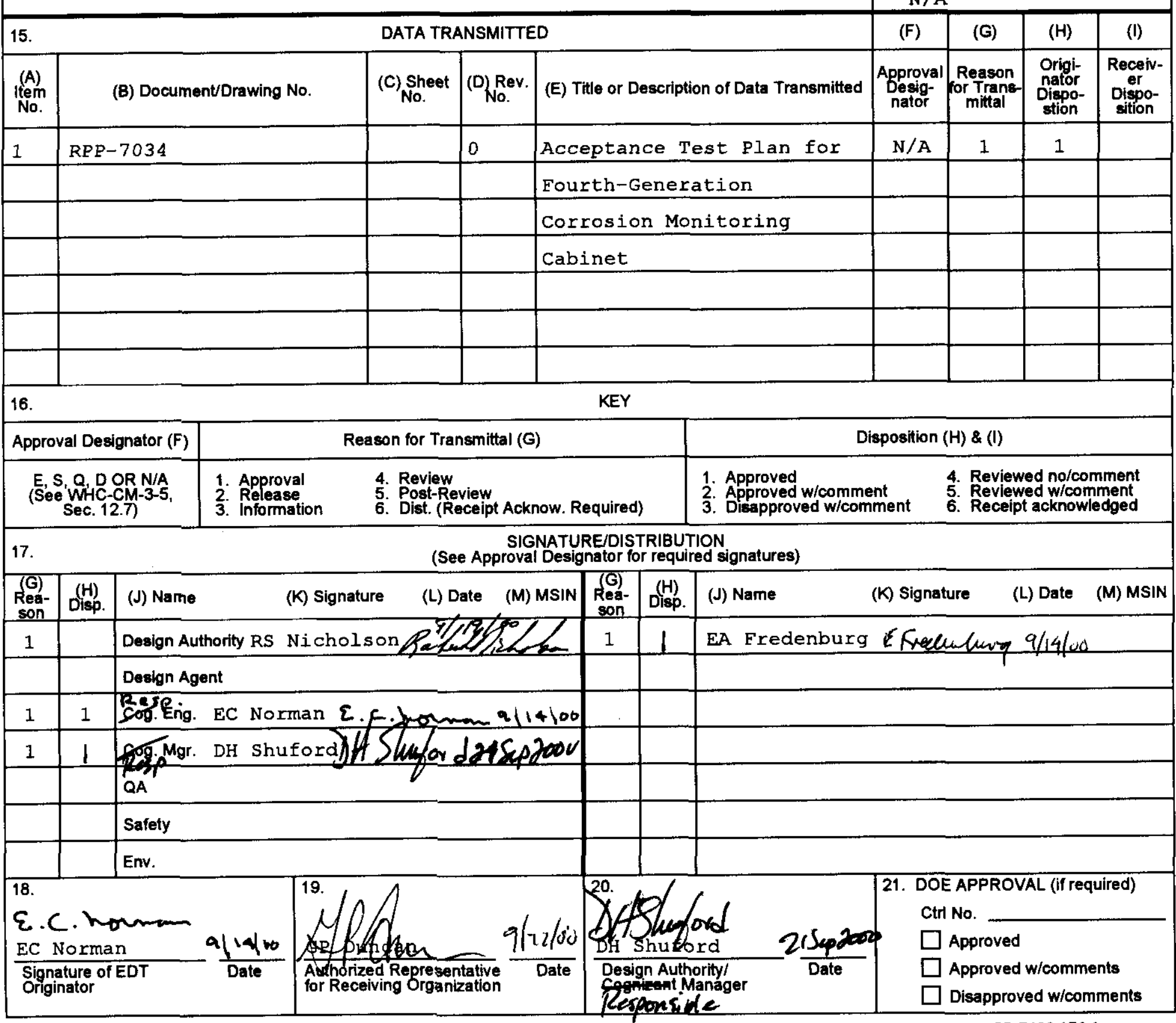




\section{DISTRIBUTION SHEET}

To

Distribution

Project Title/Work Order

RPP-7304, Acceptance Test Plan for Fourth-Generation Corrosion Monitoring Cabinet

Name

EA Fredenburg

EC Norman

RS Nicholson

JL Castleberry

GL Edgemon

GP Duncan
From
DST Maintenance \& Reliability Eng

Page 1 of 1

Date September 14,2000

EDT No. 629699

ECN No.

\begin{tabular}{|c|c|l|c|l|}
\hline MSIN & $\begin{array}{c}\text { Text } \\
\text { With All } \\
\text { Attach. }\end{array}$ & Text Only & $\begin{array}{c}\text { Attach./ } \\
\text { Appendix } \\
\text { Only }\end{array}$ & $\begin{array}{c}\text { EDT/ECN } \\
\text { Only }\end{array}$ \\
\hline R1-04 & $X$ & & & \\
\hline R1-04 & $X$ & & & \\
\hline R5-05 & $X$ & & & \\
\hline$R 3-83$ & $X$ & & & \\
\hline$S 6-15$ & $X$ & & & \\
\hline
\end{tabular}




\section{Acceptance Test Plan for Fourth-Generation Corrosion Monitoring Cabinet}

E. C. Norman

CH2M HILI Hanford Group, Inc.

Richland, WA 99352

U.S. Department of Energy Contract DE-AC06-96RL13200

$\begin{array}{lll}\text { EDT/ECN: } 629686 & \text { UC: } 2030 \\ \text { Org Code: } 74700 & \text { Charge Code: } 112671 \\ \text { B\&R Code: } & \text { EW4010000 } & \text { Total Pages: } \not 8 \\ & & \end{array}$

Key Words: corrosion monitoring/control, corrosion probe

Abstract: This Acceptance Test Plan (ATP) will document the satisfactory opearation of the corrosion monitoring cabinet dstined for operation on tank 241-AN-104.

TRADEMARK DISCLAIMER. Reference herein to any specific commercial product, process, or service by trade name, trademark, manufacturer, or otherwise, does not necessarily constitute or imply its endorsement, recommendation, or favoring by the United States Government or any agency thereof or its contractors or subcontractors.

Printed in the United States of America. To obtain copies of this document, contact: Document Control Services, P.O. Box 950, Mailstop H6-08, Richland WA 99352, Phone (509) 372-2420; Fax (509) 376-4989.
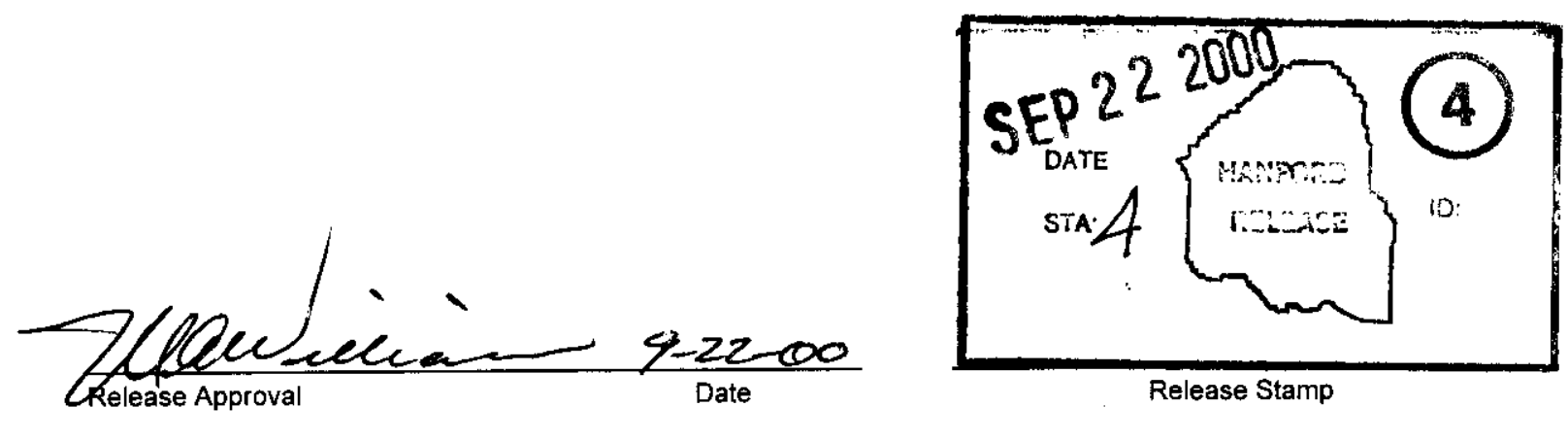

\section{Approved For Public Release}


RPP-7034, Rev. 0

\title{
ACCEPTANCE TEST PLAN FOR FOURTH-GENERATION CORROSION MONITORING CABINET
}

\author{
G. L. Edgemon \\ Hiline Engineering \& Fabrication, Inc. \\ 2105 Aviator Drive \\ Richland, Washington 99352
}




\subsection{PURPOSE}

This Acceptance Test Plan (ATP) will document the satisfactory operation of the third-generation corrosion monitoring cabinet (Hiline Engineering Part \#0004-CHM-072-C01). This ATP will be performed by the manufacturer of the cabinet prior to delivery to the site.

\subsection{TEST OBJECTIVES}

The objective of this procedure is to demonstrate and document the acceptance of the corrosion monitoring cabinet. The test will consist of a continuity test of the cabinet wiring from the end of cable to be connected to corrosion probe, through the appropriate intrinsic safety barriers and out to the 15 pin D-shell connectors to be connected to the corrosion monitoring instrument. Additional testing will be performed using a constant current and voltage source provided by the corrosion monitoring hardware manufacturer to verify proper operation of corrosion monitoring instrumentation.

\subsection{RESPONSIBILITIES}

\subsection{TEST COORDINATION AND PERFORMANCE}

A representative from the receiving organization will be responsible for the coordination, scheduling, performance, and documentation of this test procedure.

\subsection{TEST WITNESSES}

A representative from the receiving organization will perform the function of test witness. All testing shall be witnessed, verified and approved with the Test Engineer's signature.

\subsection{RECEIPT INSPECTION}

Cabinets will be subjected to receipt inspection and inspection by a certified National Electric Code (NEC) inspector from the appropriate organizations within the Hanford Site prior to acceptance by the Hanford Site.

\subsection{DOCUMENTATION}

\subsection{TEST RECORD}

Any personnel involved in the performance of this test including the Test Engineer shall fill out a line in Section 7.0 RECORDS.

Test results shall be recorded by the Test Engineer. Unacceptable conditions or readings are to be referred to Section 8.0 EXCEPTIONS. A complete working copy of this procedure and all exception records shall be maintained as lifetime records in accordance with RPP-PRO222, Rev. 0, Quality Assurance Records Standards. 


\subsection{EXCEPTIONS}

Exceptions by step number, and other notes are to be recorded under Section 8.0 EXCEPTIONS. This section must be dispositioned (including the generation of any required ECNs) and signed off by the Test Engineer prior to final ATP acceptance. If no exceptions are encountered, this section shall be so noted and closed out with the signature of the Test Engineer. During the performance of this test errors in text may be encountered which require correction/adjustment to complete the test. The correction is to be noted in the ATP and listed as an exception in Section 8.0 EXCEPTIONS.

\subsection{TEST EXECUTION RECORD}

Approval of the ATP results shall be accepted by the Test Engineer as indicated by signature in Section 9.0 TEST EXECUTION RECORD.

\subsection{TEST EQUIPMENT}

- Multimeter

- Constant Voltage/Current Source

\subsection{ACCEPTANCE TEST}

The complete acceptance test procedure is to be performed on the cabinet.

\subsection{CONTINUITY TEST}

Using a standard multimeter, electrical continuity shall be verified on each of the 24 conductors used for picking up signal from corrosion probe electrodes. To perform this continuity check, make the necessary connections between each pin on the connector that will be attached to the corrosion probe and its respective pin in the 15 pin D-type connector that will be attached to the corrosion monitoring hardware. Use the data cable that will be used in the final field installation for this test. The continuity check will be performed starting with channel 1 , and ending with channel 8.

6.1.1 Record model, serial number, and calibration expiration date of multimeter below.

Instrument: SN:

Calibration Expiration Date: 
6.1.2 Check continuity on each channel. Circle Yes or No in regard to whether continuity exists.

\begin{tabular}{|c|c|}
\hline Conductor & Continuity \\
\hline Channel 1 Working Electrode & Yes/No \\
\hline Channel 1 Counter Electrode & Yes/No \\
\hline Channel 1 Reference Electrode & Yes/No \\
\hline Channel 2 Working Electrode & Yes/No \\
\hline Channel 2 Counter Electrode & Yes/No \\
\hline Channel 2 Reference Electrode & Yes/No \\
\hline Channel 3 Working Electrode & Yes/No \\
\hline Channel 3 Counter Electrode & Yes/No \\
\hline Channel 3 Reference Electrode & Yes/No \\
\hline Channel 4 Working Electrode & Yes/No \\
\hline Channel 4 Counter Electrode & Yes/No \\
\hline Channel 4 Reference Electrode & Yes/No \\
\hline Channel 5 Working Electrode & Yes/No \\
\hline Channel 5 Counter Electrode & Yes/No \\
\hline Channel 5 Reference Electrode & Yes/No \\
\hline Channel 6 Working Electrode & Yes/No \\
\hline Channel 6 Counter Electrode & Yes/No \\
\hline Channel 6 Reference Electrode & Yes/No \\
\hline Channel 7 Working Electrode & Yes/No \\
\hline Channel 7 Counter Electrode & Yes/No \\
\hline Channel 7 Reference Electrode & Yes/No \\
\hline Channel 8 Working Electr & Yes/No \\
\hline Channel $8 \mathrm{C}$ & Yes/No \\
\hline Channel 8 Reference Electrode & Yes/No \\
\hline
\end{tabular}

6.1.3 Test Engineer sign that steps 6.1.1 through 6.1.2 are complete.

Test Engineer Date

\subsection{INSTRUMENTATION FUNCTIONAL TEST}

Using a constant current and constant voltage source of between $0.1-20$ microamps and 0.1 to $200 \mathrm{mV}$ respectively, check operation of corrosion monitoring instrumentation by putting 
instrumentation in measuring configuration and properly measuring/recording the known signal provided by the source. Constant current and voltage source should be checked for accuracy with calibrated multimeter prior to start of testing. Constant current and voltage source should be measured by corrosion monitoring software/hardware using the actual cables to be used in the final field installation. Constant current and voltage source should be measured after passing through the intrinsic safety barrier system to be used in final field installation.

Connect constant current/voltage source to appropriate pins at end of data cable to be connected to corrosion probe in final field installation. This cable should run back through the intrinsic safety barriers and be properly connected to corrosion monitoring instrumentation per vendor instruction. Launch corrosion monitoring software and record on each channel for a minimum of one minute to verify that known current/voltage signal is being properly recorded by software. Test will be considered a success on each channel if that channel records values within $+/-10 \%$ of the source values for current and voltage.

6.2.1 Record model, serial number, and calibration expiration date of multimeter below.

Instrument:

SN:

Calibration Expiration Date:

6.2.2 Record model and serial number of constant current/voltage source below.

Instrument: SN:

6.2.3 Check known constant current/voltage signal against measured current/voltage value on corrosion monitoring software/hardware.

\begin{tabular}{|c|c|c|c|c|}
\hline Channel & $\begin{array}{l}\text { Constant } \\
\text { Current } \\
\text { Source } \\
\text { Value }\end{array}$ & $\begin{array}{l}\text { Constant } \\
\text { Voltage } \\
\text { Source } \\
\text { Value }\end{array}$ & $\begin{array}{l}\text { Instrument } \\
\text { Recorded } \\
\text { Current } \\
\text { Value }\end{array}$ & $\begin{array}{l}\text { Instrumen } \\
\text { Recorded } \\
\text { Voltage } \\
\text { Value }\end{array}$ \\
\hline 1 & & - & 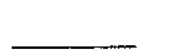 & 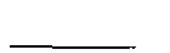 \\
\hline 2 & & 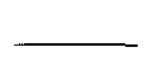 & 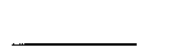 & \\
\hline 3 & & & & \\
\hline 4 & & & - & - \\
\hline 5 & & & & 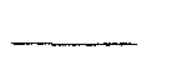 \\
\hline 6 & & & - & 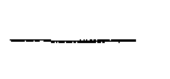 \\
\hline 8 & & & $\bar{\square}$ & $\bar{\square}$ \\
\hline
\end{tabular}


6.2.3 Test Engineer sign that steps 6.2.1 through 6.2.3 are complete.

Test Engineer Date

\subsection{RECORDS}

TEST ENGINEER

Test Engineer Sign In:

Test Engineer

Date

TEST WITNESSES

Print Name

Signature

Position

Date

\subsection{EXCEPTIONS}

\begin{tabular}{|l|l|l|l|}
\hline ITEM & STEP & DESCRIPTION & DISPOSITION \\
\hline & & & \\
\hline & & & \\
\hline & & & \\
\hline
\end{tabular}


TEST APPROVED WITH/WITHOUT EXCEPTIONS (CIRCLE WITH OR WITHOUT):

Test Engineer

Date

9.0 TEST EXECUTION RECORD

\begin{tabular}{|l|l|l||}
\hline \hline Section & Accept/Reject & Remarks \\
\hline 6.1 & & \\
& & \\
\hline \hline 6.2 & & \\
& & \\
\hline
\end{tabular}

Test Engineer

Date 